\title{
The Effect of Organic Manure and Potassium Fertilizers on Growth, Yield and Fruit Quality of Anna Apple Trees
}

\author{
Mohamed R. El-Shenawi and Mohamed E. Moursy ${ }^{2}$
}

\begin{abstract}
The present study was carried out at a private orchard at El-Akrisha Kafr El-Dawar district, Behera Governorate, Egypt, on eight years old "Anna" apple trees (Malus domestica, Bork) buded on Balady rootstock during the 2008/2009 and 2009/2010 growing seasons under surface irrigation system. This investigation aimed to study the response of Anna apple trees to organic amendment type (cattle (M1) and horse (M2) manures) with rate of $25 \mathrm{~kg} /$ tree/year $\left(20 \mathrm{~m}^{3} / \mathrm{fed} / \mathrm{year}\right)$, with two different types of potassium fertilizers $\left(\mathrm{K}_{2} \mathrm{SO}_{4}\right.$ (SOP) \& $\mathrm{KCl}$ (MOP) with three levels from each type $(0,50$ and $\left.100 \mathrm{~kg} \mathrm{~K}_{2} \mathrm{O} / \mathrm{fed} / \mathrm{year}\right)$. The results indicated that horse manure (M2) was more effective than cattle manure in improving the measured parameters (number of leaves/shoot, leaf area, number of flowers/ cluster, fruit set $\%$, fruit weight, fruit length, fruit diameter as well as yield, anthocyanine $\%$, starch $\%$, TSS $\%$, average fruit firmness $\left(\mathrm{lb} / \mathrm{inch}^{2}\right)$, total sugars \%, acidity \% and leaf NPK content). The data clarified that increasing the rate of potassium significantly increased all tested parameters for the two types of potassium fertilizers compared with control (zeroK $\left.{ }_{2} \mathrm{O}\right)$. On the other hand, potassium chloride gave the best results to improve the studied characters compared with potassium sulfate. The results also indicated that the best treatment was when fertilizing Anna apple trees with horse or cattle manure with rate 20 $\mathrm{m}^{3} /$ fed/year and applying $100 \mathrm{~kg} \mathrm{K2O}\left(\mathrm{K}_{2} \mathrm{SO}_{4}\right.$ or $\left.\mathrm{KCl}\right)$. The yield of these treatments reached 21 and 17 ton/fed for horse and cattle manure, respectively compared with control (11 ton/year).
\end{abstract}

Key words: Apple trees, fertilizer, organic manure and potassium.

\section{INTRODUCTION}

Apple (Malus domestica, Bork.) is considered as one of the most important fruit crops grown in the world. Apple fruits are highly appreciated by Egyptian consumers and considered as a good source of energy and vitamin $\mathrm{A}$ and $\mathrm{C}$.

The Egyptian soils are cultivated twice and in some areas 3 times per year with high crop yields which remove continuously large amounts of potassium from soils without replenishing the removal of $\mathrm{K}$ by crops. This show that soil fertility, which is one of the important natural resources requires fertilizers to combat the worldwide degradation of fertile soils (Abd El-
Hadi,1989 and Abd El-Hadi et al., 1990). Potassium $(\mathrm{K})$ is very important in the plant photosynthesis process and helping plants metabolize their food to get energy, potassium is involved in many aspects of plant physiology (Marschner, 1995), activates more than enzyme systems, aids in photosynthesis, promotes water uptake, regulates nutrients translocation in plant, favours carbohydrate transport and storage, enhances nitrogen uptake and protein synthesis and increases yield. ElMorshedy 1997 and Attala 1997, reported that potassium fertilization increased weight, fruit TSS and total sugars of apple fruits. Potassium plays an important role in the transport of assimilates and nutrients, mainly sucrose and amino acids must be transported from the leaves to the site of their use or storage in fruits, roots, tubers, seeds, and grains (Mengel, 1997). The amount of potassium required to obtain a significant improvement in fruit size and/ or color of apples in similar to that recommended for soil application; $50 \mathrm{~kg}$ or more per acre (Hanson, 1996).

Animal manure contains varying levels of nutrients and organic matter. The disadvantage of adding manure to orchards is that the nitrogen is released over a prolonged period of time. This slow release means that perennial crop continues to receive nitrogen throughout the year, resulting in poor fruit color, excessive terminal growth and delayed hardening of the woody tisse. Organic matter contains varying levels of nutrients which improve fruit quality, increase total nitrogen and increase significantly soil available $\mathrm{N}, \mathrm{P}$, and $\mathrm{K}$ (Montassser, 1987, Mahmoud 1994 and Badran et al., 2000, Saleh et al., 2006 and Soliman et al., 2006).

The aim objective of this study is to examine the effect of potassium fertilizers (type and rate) and animal manure on vegetative growth, yield, and fruit quality of Anna apple trees.

\section{MATERIALS AND METHODS}

The present study was carried out during two successive seasons of 2008/2009and 2009/2010 in a private orchard at El-Akrisha, Kafr El-Dawar district, Behera Governorate, Egypt on "Anna" apple trees (Malus domestica, Bork.) ,8 years old, buded on Balady rootstock and spaced at 4 meters apart. The soil of the orchard is clay type, under surface irrigation system, soil samples were randomly taken from two depths $(0-50 \mathrm{~cm}$

\footnotetext{
${ }^{1}$ Tropical Fruits Dept., Horticulture Res. Institute, ARC.

${ }^{2}$ Soil Fertility and Plant Nutrition Dept., Soil, Water and environment Res. Institute

Received December20, 2010, Accepted December30, 2010.
} 
Mohamed R. El-Shenawi and Mohamed E. Moursy: The Effect of Oganic Manure and Potassium Fertilizers on Growth, Yield ...

and $50-100 \mathrm{~cm})$.Main chemical and physical soil characters were made according to Page (1982) are shown in Tables (1and 2). The chemical properties of cattle and horse manures are shown in Table (3).

The analysis of soil and manures were carried out according to the methods described by Page ( 1982). Healthy apple trees nearly uniform as possible in growth vigor and productivity were chosen for this investigation. The trees were subjected under flooding irrigation system.

This experiment included twelve treatments as follows:

1-(20 $\mathrm{m}^{3}$ cattle manure +zero potassium sulfate)/fed/year.

2- $\left(20 \mathrm{~m}^{3}\right.$ cattle manure/ $+50 \mathrm{Kg} \mathrm{K} 2 \mathrm{O}$ potassium sulfate)/fed/year.

$3-\left(20 \mathrm{~m}^{3}\right.$ cattle manure $+100 \mathrm{Kg} \mathrm{K} 2 \mathrm{O}$ potassium sulfate)/fed/year.

4-(20 $\mathrm{m}^{3}$ cattle manure +zero potassium chloride)/fed/year.

$5-\left(20 \mathrm{~m}^{3}\right.$ cattle manure $+50 \mathrm{Kg} \mathrm{K} 2 \mathrm{O}$ potassium chloride)/fed/year.

Table 1. Soil chemical properties of the field experiment

\begin{tabular}{|c|c|c|c|c|c|c|c|c|c|c|c|c|c|c|c|}
\hline \multirow[t]{2}{*}{ Season } & \multirow{2}{*}{$\begin{array}{c}\text { Depth } \\
\text { cm }\end{array}$} & \multirow[t]{2}{*}{ pH } & \multirow[t]{2}{*}{ EC } & \multirow[t]{2}{*}{ OM\% } & \multicolumn{4}{|c|}{ Soluble cations me/L } & \multicolumn{4}{|c|}{ Soluble anions $\mathrm{me} / \mathrm{L}$} & \multicolumn{3}{|c|}{ NPK mg kg-1 } \\
\hline & & & & & $\mathbf{C a}^{2+}$ & $\mathrm{Mg}^{2+}$ & $\mathbf{N a}^{+}$ & $\mathbf{K}^{+}$ & $\mathrm{CO}_{3}^{2-}$ & $\mathrm{HCO}_{3}^{-}$ & $\mathrm{Cl}^{-}$ & SO4 & $\mathbf{N}$ & $\mathbf{P}$ & $\mathbf{K}$ \\
\hline \multirow{2}{*}{$2008 / 2009$} & $0-50$ & 8.26 & 4.22 & 1.85 & 10.3 & 7.6 & 20.1 & 4.2 & 0.0 & 8.3 & 17.4 & 16.5 & 600 & 8.0 & 220 \\
\hline & $50-100$ & 7.67 & 1.15 & 0.35 & 3.3 & 1.4 & 6.6 & 0.7 & 0.0 & 2.4 & 3.4 & 5.7 & 200 & 4.6 & 97 \\
\hline \multirow{2}{*}{ 2009/2010 } & $0-50$ & 8.32 & 4.37 & 1.79 & 12.4 & 8.3 & 18.6 & 4.4 & 0.0 & 10.2 & 14.6 & 18.9 & 700 & 9.2 & 235 \\
\hline & $50-100$ & 7.80 & 1.46 & 0.48 & 3.7 & 1.2 & 8.7 & 1.0 & 0.0 & 3.1 & 5.4 & 6.1 & 300 & 4.2 & 113 \\
\hline
\end{tabular}

$* \mathrm{pH}$ in soil suspension $(1: 2.5)$

** EC, anions, and cations (soil paste extract)

*** Available $\mathrm{P}$ extracted by $\mathrm{NaHCO}_{3}$, and available $\mathrm{K}$ extracted by Amm.acetate.

Table 2. Particle size distribution and calcium carbonate content

\begin{tabular}{|c|c|c|c|c|c|c|}
\hline \multirow{2}{*}{ Season } & \multirow{2}{*}{$\begin{array}{c}\text { Depth } \\
\text { cm }\end{array}$} & \multirow{2}{*}{$\begin{array}{c}\mathrm{CaCO3} \\
\%\end{array}$} & \multicolumn{3}{|c|}{ Particle size distribution \% } & \multirow{2}{*}{ Texture } \\
\hline & & & Clay & Silt & Sand & \\
\hline \multirow{2}{*}{$2008 / 2009$} & $0-50$ & 10.23 & 48.04 & 30.26 & 21.70 & Clay \\
\hline & $50-100$ & 8.45 & 36.91 & 39.74 & 23.35 & Clay Loam \\
\hline \multirow{2}{*}{$2009 / 2010$} & $0-50$ & 9.86 & 47.90 & 31.26 & 20.84 & Clay \\
\hline & $50-100$ & 8.21 & 38.71 & 35.73 & 25.56 & Clay Loam \\
\hline
\end{tabular}

Table 3. Chemical properties of cattle and horse manure

\begin{tabular}{lcccc}
\hline \multirow{2}{*}{ Components } & \multicolumn{2}{c}{ Cattle Manure } & \multicolumn{2}{c}{ Horse Manure } \\
\cline { 2 - 5 } & $\mathbf{2 0 0 8 / 2 0 0 9}$ & $\mathbf{2 0 0 9 / 2 0 1 0}$ & $\mathbf{2 0 0 8 / 2 0 0 9}$ & $\mathbf{2 0 0 9 / 2 0 1 0}$ \\
\hline pH & 8.4 & 8.1 & 8.5 & 8.6 \\
\hline EC, ds/cm & 12.12 & 13.20 & 14.05 & 15.17 \\
\hline O.M \% & 21.04 & 22.27 & 28.17 & 31.32 \\
\hline Total N \% & 0.83 & 0.78 & 1.23 & 1.18 \\
\hline C:N ratio & 12.4 & 12.8 & 11.3 & 0.33 \\
\hline Total P \% & 0.26 & 0.31 & 0.35 & 0.74 \\
\hline Total K \% & 0.61 & 0.64 & 0.86 & 20.21 \\
\hline Moisture \% & 25.27 & 24.59 & 21.66 & \\
\hline
\end{tabular}

6- $\left(20 \mathrm{~m}^{3}\right.$ cattle manure $+100 \mathrm{Kg} \mathrm{K} 2 \mathrm{O}$ potassium chloride)/fed/year.

7-(20 $\mathrm{m}^{3}$ horse manure +zero potassium sulfate)/fed /year.

8- $\left(20 \mathrm{~m}^{3}\right.$ horse manure $+50 \mathrm{KgK} 2 \mathrm{O}$ potassium sulfate)/fed/year.

- $\left(20 \mathrm{~m}^{3}\right.$ horse manure $+100 \mathrm{Kg} \mathrm{K} 2 \mathrm{O}$ (potassium sulfate)/fed/year.

10- $\left(20 \mathrm{~m}^{3}\right.$ horse manure +zero potassium chloride $) /$ fed /year.

$1-\left(20 \mathrm{~m}^{3}\right.$ horse manure $+50 \mathrm{KgK} 2 \mathrm{O}$ potassium chloride)/fed/year.

2- $\left(20 \mathrm{~m}^{3}\right.$ horse manure $+100 \mathrm{Kg} \mathrm{K} 2 \mathrm{O}$ potassium chloride)/fed/year.

Twelve fertilization treatments were arranged in a split- split plot design and each treatment was replicated four times and each replicate consisted of 4 trees according to Snedecor and Cochran (1990). Cattle and tillage at the end of December. Potassium fertilizers horse manures were added to surface soil followed by 
were added at the end of January in both seasons. Phosphorus fertilizer ( $1 \mathrm{~kg}$ super phosphate /tree/year) was added with organic manure. Nitrogen fertilizer $(2 \mathrm{~kg}$ ammonium nitrate) was added in 4 equal doses, the first was on March, 1, the second 20 days after first, the third 15 days after the second,the fourth after harvest.

\section{Measured parameters:}

- Number of flowers/cluster and fruit set were determined on selected branches1.5" diameter according to Agnello et al. (1999).

- The percentage of flowers set was assessed on the same branches by counting the remaining fruits in late May when the fruit drop was finished.

- Fruits were harvested in late June in both seasons. All fruits on each tree were counted; weighed and average fruit (weight, length and diameter) were estimated.

- Fruit firmness was recorded two sides of each fruit using EPT-1 pressure tester fitted with an $11.1 \mathrm{~mm}$ (0.43inch).

To determine anthocyanine pigment, one gm of the apple peel tissues was removed from by spaced location at the equatorial region of each fruit sample, net anthocyanine was extracted by ethanolic $\mathrm{HCl}$ (which consisted of $98 \mathrm{ml}$ ethanol $95 \%+2 \mathrm{ml}$ concentrated $\mathrm{HCl})$. Extraction was carried out for 24 hours at $2{ }^{\circ} \mathrm{C}$ with $50 \mathrm{ml}$ of the prepared solution. Petrolium ether $(150 \mathrm{ml})$ was added to pigment extraction of each sample, filtrated and completed to a final volume of 100 $\mathrm{ml}$ with ethanol. The optical densities of the filtrates were measured by a Carle Zeiss Photo Electric Colorimeter at 530 n.m. Anthocyanine was expressed as $\mathrm{O} . \mathrm{D} / \mathrm{g}$ of fresh weight $(\mathrm{mg} / 100 \mathrm{gm}$ fresh weight $)$ according to Rabino et al. (1977).

The percentage of total soluble solids in the juice of each fruit was determined by a hand refractometer, fruit acidity percentage (expressed as malic acid), total sugar percent and starch percent were determined according to A.O.A.C.(2000).

For leaf mineral analysis, twenty five leaves on each experimental trees were collected from mid portion of current season shoots. Leaf samples were washed by several times with tap water and distilled water to remove any spray residues and other deposits. The leaf samples were then dried to a constant weight in paper bag a drying oven at $70-80^{\circ} \mathrm{C}$. Leaf sample were ground by stainless steel rotary knife, the ground samples were redried to a constant weight. From the ground dried material of each sample, $0.3 \mathrm{gm}$ was digested with sulphoric acid and hydrogen peroxide according to (FAO, 1980). N, $\mathrm{P}$ and $\mathrm{K}$ concentrations were determined using semi-automatic nitrogen distillation unit, Spectrophotometer 21D and Jenway Flame Photometer, respectively according to the methods described by Westerman, (1990).

\section{Statistical analysis:}

The obtained data were analyzed using the CoHort Software (1986) statistical package. Average values from the four replicates of each treatment were interpreted using the analysis of variance (ANOVA). The Duncan's Test was used for comparison between means as advised by Steel and Torrie (1980).

\section{RESULTS AND DISCUSSION}

\section{1- Vegetative growth:}

Data presented in Table (4) show main, sub main and interaction effects of the three tested factors including (cattle and horse manures) with three levels of $\mathrm{K}_{2} \mathrm{SO}_{4}$ and $\mathrm{KCl}$ with concentrated of 0,50 and $100 \mathrm{Kg}$ of $\mathrm{K}_{2} \mathrm{O}$.

\subsection{Main and submain effect}

The highest results recorded in this regard were (25.50 and 23.11) for number of leaves/ shoot for horse and cattle manure and (38.94 and 37.94) for leaf area for horse and cattle manure during first season and the same trend was found in the second season. Increasing $\mathrm{K}$ level, also, increase these parameters. These results are in harmony with Awad and El-Shenawi (2005) they found that organic manure caused increased in vegetative growth on Williams banana variety.

\subsection{Interaction effect}

The increasing of $\mathrm{K}$ rate with horse manure showed a significant increase in number of leaves and leaf area with $\left(20 \mathrm{~m}^{3}\right.$ horse manure $+100 \mathrm{~kg} \mathrm{~K} 2 \mathrm{O}$ (in form of $\mathrm{KCl}$ )/ fed/ year than other treatments during two seasons. Land application of organic manure increases soil organic matter and improves the soil properties and this effect will be reflected on increasing vegetative growth. These results are in agreement with those of El-Shenawi (2000), El-Kouny et al. (2004), Fayed (2005) and Eman et al. (2010).

\section{2- Flowers and fruit set}

Data presented in Table (5) declared that main and interaction effects of the three tested factors in the field experiment on Anna apple under clay soil conditions. The obtained data showed that there were significant effects due to the treatments on the Anna apple trees concerning number of flowers/cluster and fruit set \% during the two growing seasons. 
Table 4. The effect of animals manure and potassium fertilizers on number of leaves/shoot and leaf area of Anna apple trees

\begin{tabular}{|c|c|c|c|c|c|c|}
\hline \multirow{2}{*}{ Treatments } & & & \multicolumn{2}{|c|}{ Number of leaves/ shoot } & \multicolumn{2}{|c|}{ Leaf area $\left(\mathrm{cm}^{2}\right)$} \\
\hline & & & $2008 / 2009$ & $2009 / 2010$ & $2008 / 2009$ & $2009 / 2010$ \\
\hline \multirow{6}{*}{ Cattle manure } & \multirow{3}{*}{$\mathrm{K}_{2} \mathrm{SO}_{4}$} & 0 & 21.00 & 19.00 & 36.70 & 37.00 \\
\hline & & 50 & 22.30 & 23.00 & 38.00 & 38.00 \\
\hline & & 100 & 25.30 & 26.70 & 39.00 & 41.00 \\
\hline & \multirow{3}{*}{ KCl } & 0 & 21.10 & 19.20 & 36.50 & 37.20 \\
\hline & & 50 & 22.00 & 25.30 & 38.00 & 39.70 \\
\hline & & 100 & 27.00 & 28.00 & 39.70 & 41.00 \\
\hline \multirow{6}{*}{ Horse manure } & \multirow{3}{*}{$\mathrm{K}_{2} \mathrm{SO}_{4}$} & 0 & 22.30 & 19.70 & 36.70 & 38.00 \\
\hline & & 50 & 26.00 & 26.00 & 39.00 & 39.00 \\
\hline & & 100 & 26.70 & 29.00 & 41.00 & 42.00 \\
\hline & \multirow{3}{*}{ KCl } & 0 & 22.50 & 20.00 & 36.80 & 38.20 \\
\hline & & 50 & 26.70 & 28.00 & 39.70 & 41.00 \\
\hline & & 100 & 29.00 & 31.30 & 41.30 & 44.00 \\
\hline L.S.D. 0.05 & & & 1.681 & 1.738 & 1.766 & 1.827 \\
\hline \multirow{2}{*}{ Manures } & Cattle & & 23.11 & 23.50 & 37.94 & 39.05 \\
\hline & Horse & & 25.50 & 25.61 & 38.94 & 40.44 \\
\hline L.S.D 5\% & & & 1.26 & 1.45 & 0.71 & 0.63 \\
\hline \multirow{2}{*}{ K-Type } & $\mathrm{K}_{2} \mathrm{SO}_{4}$ & & 23.94 & 23.88 & 38.33 & 39.27 \\
\hline & KCl & & 24.66 & 25.22 & 38.55 & 40.22 \\
\hline L.S.D 5\% & & & 0.61 & 1.12 & 0.55 & 0.41 \\
\hline \multirow{3}{*}{ K-Levels } & Zero K & & 12.66 & 19.33 & 36.50 & 37.50 \\
\hline & $50 \mathrm{~K}_{2} \mathrm{O}$ & & 24.25 & 25.58 & 38.66 & 39.50 \\
\hline & $100 \mathrm{~K}_{2} \mathrm{O}$ & & 27.00 & 28.25 & 40.16 & 42.25 \\
\hline L.S.D 5\% & & & 0.84 & 1.09 & 0.88 & 1.14 \\
\hline
\end{tabular}

Table 5. The effect of animals manure and potassium fertilizers on number of flowers / cluster and fruit set of Anna apple trees

\begin{tabular}{|c|c|c|c|c|c|c|}
\hline \multirow{2}{*}{ Treatments } & & & \multicolumn{2}{|c|}{ Number flowers/ cluster } & \multicolumn{2}{|c|}{ Fruit set (\%) } \\
\hline & & & $2008 / 2009$ & $2009 / 2010$ & $2008 / 2009$ & $2009 / 2010$ \\
\hline \multirow{6}{*}{ Cattle manure } & $\mathrm{K}_{2} \mathrm{SO}_{4}$ & 0 & 9.10 & 10.70 & 13.00 & 15.00 \\
\hline & & 50 & 11.00 & 12.00 & 14.70 & 19.70 \\
\hline & & 100 & 11.70 & 14.00 & 16.70 & 23.00 \\
\hline & KCl & 0 & 9.00 & 10.60 & 13.20 & 15.20 \\
\hline & & 50 & 10.00 & 13.70 & 15.30 & 19.30 \\
\hline & & 100 & 12.00 & 15.00 & 17.30 & 23.70 \\
\hline \multirow{6}{*}{ Horse manure } & $\mathrm{K}_{2} \mathrm{SO}_{4}$ & 0 & 10.70 & 11.00 & 13.30 & 18.00 \\
\hline & & 50 & 11.70 & 12.70 & 16.00 & 21.00 \\
\hline & & 100 & 13.00 & 16.00 & 17.30 & 25.00 \\
\hline & KCl & 0 & 10.80 & 11.20 & 13.40 & 18.10 \\
\hline & & 50 & 11.00 & 13.70 & 16.00 & 23.00 \\
\hline & & 100 & 13.70 & 17.70 & 18.30 & 27.00 \\
\hline L.S.D. 0.05 & & & 1.553 & 1.225 & 1.206 & 1.328 \\
\hline \multirow{2}{*}{ Manures } & Cattle & & 10.44 & 12.50 & 14.94 & 19.55 \\
\hline & Horse & & 11.61 & 13.27 & 15.83 & 21.88 \\
\hline L.S.D $5 \%$ & & & 1.09 & 0.63 & 0.47 & 1.24 \\
\hline \multirow{2}{*}{ К-Туре } & $\mathrm{K}_{2} \mathrm{SO}_{4}$ & & 11.00 & 12.50 & 15.16 & 20.44 \\
\hline & KCl & & 11.05 & 13.27 & 15.61 & 21.00 \\
\hline L.S.D $5 \%$ & & & $\mathbf{0 . 5 7}$ & 1.23 & 0.48 & 0.67 \\
\hline \multirow{3}{*}{ K-Levels } & Zero K & & 9.66 & 10.58 & 13.33 & 17.00 \\
\hline & $50 \mathrm{~K}_{2} \mathrm{O}$ & & 10.83 & 12.92 & 15.50 & 20.75 \\
\hline & $100 K_{2} \mathrm{O}$ & & 12.58 & 15.17 & 17.33 & 24.42 \\
\hline L.S.D 5\% & & & 0.77 & 0.728 & 0.60 & 1.15 \\
\hline
\end{tabular}




\subsection{Main and sub main effect}

The highest results in Table (5) were recorded (11.61 and 10.44 average of the first season) for horse and cattle manures for number of flowers/ cluster and (15.83 and 14.94)for fruit set \%, respectively. Increasing $\mathrm{K}$ levels, also, increase these parameters. The data gave the same trend in the second season.

\subsection{Interaction effect}

Data in Table (5) declared that application of organic manure and potassium fertilization $\left(20 \mathrm{~m}^{3}\right.$ horse manure $+100 \mathrm{~kg} \mathrm{~K} 2 \mathrm{O}$ (in form of $\mathrm{KCl} /$ fed /year) to apple trees caused significant increase in number of flowers/cluster and fruit set \% and gave the best results in both seasons of study (Stiles and Reid 1991and Abou El-Khashab et al., 2005).

Organic manure contains all the essential micro and macro elements required for plant growth .Land application of organic manure increases soil organic matter and improves soil organic matter and improves a number of soil properties including texture, waterholding capacity, oxygen content and soil fertility .It also increases water infiltration rates, reduces nutrient leaching and increases crop yields (Cassman et al. 1995). Gething (1986) reported that potassium performs many functions in plant metabolism, promoting photosynthesis, conserving water, speeding up the transport of the products of metabolism between different parts of plant .At all levels in plants, within individual cells, tissues and in long distance transport via the xylem and phloem, $K$ exists as a free ion in solution or as an electrostatically bound cation .Potassium takes part in many essential processes: enzyme activation, protein synthesis, photosynthesis, phloem transport, osmoregulation, cation-anion balance, stomatal movement and light-driven mastic movements (Marschner, 1995). These results are in accordance with that obtained by Stiles and Reid (1991).

\section{3- Fruit characters}

Data presented in Table (6) show main, sub main and interaction effects of the three tested factors including (cattle and horse manures) with three levels of $\mathrm{K}_{2} \mathrm{SO}_{4}$ and $\mathrm{KCl}$ with levels of 0,50 and $100 \mathrm{Kg}$ of $\mathrm{K}_{2} \mathrm{O}$. The results indicated that there were significant effects due to the treatments on the apple trees fruit characters including (fruit weight, length and diameter) during the two seasons.

\subsection{Main and sub main effect}

In Table (6) the average of horse and cattle manure were (139.66 and 135.77) for fruit weight $(\mathrm{gm})$ in first season; (13.06 and 12.367) for fruit length $(\mathrm{cm})$ and 3.883 and 6.783 ) for fruit diameter $(\mathrm{cm})$, respectively.
Increasing $\mathrm{K}$ levels, increase the studied parameters. Similar trend was obtained in the second season.

\subsection{Interaction effect}

The results presented in Table (6) indicated that application of organic manure and potassium chloride fertilizer $\left[20 \mathrm{~m}^{3}\right.$ horse $+100 \mathrm{Kg} \mathrm{K} \mathrm{K}_{2} \mathrm{O}$ (in form of $\mathrm{KCl}$ )/ $\mathrm{fed} /$ year] to apple trees increased (fruit weight, length and diameter) significantly in the two seasons compared with control. The obtained data are in accordance with that obtained by Neilsen et al. (2004). They found that organic manure and potassium increased fruit (weight, length and diameter) in apple fruits.

\section{4- Yield characters}

Data presented in Table(7) illustrate main and interaction effects of the three tested factors including organic amendments type, potassium type and potassium fertilizers level. The results showed that their were significant effects due to the treatments on the Anna apples trees yield characters including yield $(\mathrm{Kg}) /$ tree and yield (ton)/ fed during the two growing seasons.

\subsection{Main and sub main effect}

The data presented in Table(7) showed that the values ranged between (41.88 and 38.88) in first season for horse and cattle manures for yield $(\mathrm{Kg}) /$ tree and (13.90 and 13.20) for yield (ton)/ fed, respectively. Results were nearly similar in the second season. Increasing $\mathrm{K}$ levels increased the studied parameters. Results are in line with El-Kouny et al. (2004)and Naik and SrihiHari Babu (2007).

\subsection{Interaction effect}

Combined effects of cattle and horse manure type of potassium mineral and level of mineral potassium fertilizer to apple trees on the yield characters were presented in Table (7). It is clear that most interactions were statistically significant, which indicate a high degree of interdependence between the studied factors. This was apparent with all considered yield parameters. The most pronounced increase in yield $\mathrm{Kg}$ /tree and yield (ton/fed) were obtained for combination of horse or cattle manure with high rate of potassium chloride in both growing seasons. These results are in harmony with Awad and El-Shenawi (2005) and El-Shenawi and ElSayed (2005). They reported that organic manure and potassium increase yield in banana plants.

\section{5- Fruit quality 1}

Data presented in Table (8) illustrated main, sub main and interaction effects of the three tested factors in the trial on Anna apple fruit quality under the same conditions. The obtained results showed that there were significant effects due to the treatments on the Anna 
Table 6. The effect of animals manure and potassium fertilizers on fruit weight, fruit length and fruit diameter of Anna apple trees

\begin{tabular}{|c|c|c|c|c|c|c|c|c|}
\hline \multirow{2}{*}{\multicolumn{3}{|c|}{ Treatments }} & \multicolumn{2}{|c|}{ Fruit weight (gm) } & \multicolumn{2}{|c|}{ Fruit length $(\mathrm{cm})$} & \multicolumn{2}{|c|}{ Fruit diameter $(\mathbf{c m})$} \\
\hline & & & $2008 / 2009$ & $2009 / 2010$ & $2008 / 2009$ & $2009 / 2010$ & $2008 / 2009$ & $2009 / 2010$ \\
\hline \multirow{6}{*}{$\begin{array}{l}\text { Cattle } \\
\text { manure }\end{array}$} & $\mathrm{K}_{2} \mathrm{SO}_{4}$ & 0 & 122 & 121 & 11.73 & 11.83 & 6.27 & 6.00 \\
\hline & & 50 & 136 & 140 & 12.10 & 12.37 & 6.40 & 6.43 \\
\hline & & 100 & 147 & 145 & 12.57 & 12.73 & 6.70 & 6.63 \\
\hline & $\mathrm{KCl}$ & 0 & 125 & 122 & 11.83 & 11.90 & 6.31 & 6.20 \\
\hline & & 50 & 140 & 143 & 12.67 & 12.93 & 6.90 & 7.00 \\
\hline & & 100 & 147 & 150 & 13.43 & 13.87 & 7.10 & 7.50 \\
\hline \multirow{6}{*}{$\begin{array}{l}\text { Horse } \\
\text { manure }\end{array}$} & $\mathrm{K}_{2} \mathrm{SO}_{4}$ & 0 & 125 & 124 & 11.97 & 12.03 & 6.63 & 6.17 \\
\hline & & 50 & 138 & 140 & 12.70 & 13.27 & 6.73 & 6.77 \\
\hline & & 100 & 149 & 146 & 13.40 & 13.53 & 6.80 & 7.00 \\
\hline & $\mathrm{KCl}$ & 0 & 127 & 125 & 11.88 & 11.95 & 6.10 & 11.88 \\
\hline & & 50 & 148 & 149 & 13.77 & 13.9 & 7.33 & 13.77 \\
\hline & & 100 & 154 & 156 & 14.53 & 14.9 & 7.77 & 14.53 \\
\hline L.S.D. 0.05 & & & 6.41 & 7.66 & 0.03 & $\mathbf{0 . 0 3}$ & 0.70 & 0.03 \\
\hline \multirow{2}{*}{ Manures } & Cattle & & 135.77 & 13.38 & 12.37 & 12.59 & 6.78 & 6.56 \\
\hline & Horse & & 139.66 & 139.55 & 13.06 & 13.24 & 6.88 & 6.86 \\
\hline L.S.D 5\% & & & 6.36 & 4.38 & 0.20 & 0.27 & 1.01 & 0.43 \\
\hline \multirow{2}{*}{ K-Type } & $\mathrm{K}_{2} \mathrm{SO}_{4}$ & & 135.64 & 135.72 & 12.41 & 12.63 & 6.59 & 6.48 \\
\hline & $\mathrm{KCl}$ & & 139.50 & 140.22 & 13.02 & 13.21 & 7.08 & 6.94 \\
\hline L.S.D 5\% & & & 1.632 & 3.279 & 0.06 & 0.106 & 0.45 & 0.15 \\
\hline \multirow{3}{*}{ K-Levels } & Zero K & & 123.50 & 122.16 & 11.84 & 11.93 & 6.45 & 6.03 \\
\hline & $50 \mathrm{~K} 2 \mathrm{O}$ & & 140.58 & 142.75 & 12.82 & 13.12 & 7.02 & 6.82 \\
\hline & $100 \mathrm{~K} 2 \mathrm{O}$ & & 149.08 & 149.00 & 13.48 & 13.71 & 7.03 & 7.22 \\
\hline L.S.D 5\% & & & 3.21 & 3.83 & 0.11 & 0.14 & 0.41 & 0.20 \\
\hline
\end{tabular}

Table 7. The effect of animals manure and potassium fertilizers on yield $\mathrm{kg} /$ tree and yield ton/fed of Anna apple trees

\begin{tabular}{|c|c|c|c|c|c|c|}
\hline \multirow{2}{*}{ Treatments } & & & \multicolumn{2}{|c|}{ Yield $(\mathrm{kg}) /$ tree } & \multicolumn{2}{|c|}{ Yield (ton)/ fed } \\
\hline & & & $2008 / 2009$ & $2009 / 2010$ & $2008 / 2009$ & $2009 / 2010$ \\
\hline \multirow{6}{*}{ Cattle manure } & $\mathrm{K}_{2} \mathrm{SO}_{4}$ & 0 & 30.00 & 32.30 & 10.20 & 10.95 \\
\hline & & 50 & 36.70 & 37.70 & 12.48 & 12.70 \\
\hline & & 100 & 45.30 & 51.30 & 15.40 & 17.45 \\
\hline & $\mathrm{KCl}$ & 0 & 31.10 & 33.00 & 10.30 & 11.00 \\
\hline & & 50 & 41.30 & 43.00 & 14.05 & 14.60 \\
\hline & & 100 & 49.00 & 52.00 & 16.65 & 17.68 \\
\hline \multirow{6}{*}{ Horse manure } & $\mathrm{K}_{2} \mathrm{SO}_{4}$ & 0 & 33.70 & 37.00 & 11.45 & 12.58 \\
\hline & & 50 & 37.00 & 41.00 & 12.58 & 13.95 \\
\hline & & 100 & 48.00 & 62.30 & 16.30 & 21.00 \\
\hline & $\mathrm{KCl}$ & 0 & 33.50 & 37.40 & 11.50 & 12.70 \\
\hline & & 50 & 42.30 & 50.00 & 14.38 & 17.00 \\
\hline & & 100 & 56.70 & 62.70 & 19.28 & 21.40 \\
\hline L.S.D. 0.05 & & & 3.29 & 3.11 & 3.16 & 2.75 \\
\hline \multirow{2}{*}{ Manures } & Cattle & & 38.88 & 41.44 & 13.20 & 14.10 \\
\hline & Horse & & 41.88 & 48.33 & 13.90 & 16.40 \\
\hline L.S.D 5\% & & & 2.89 & 2.28 & 2.29 & 0.36 \\
\hline \multirow[t]{2}{*}{ K-Type } & $\mathrm{K}_{2} \mathrm{SO}_{4}$ & & 38.63 & 43.61 & 13.00 & 14.80 \\
\hline & $\mathrm{KCl}$ & & 42.61 & 46.16 & 14.00 & 15.70 \\
\hline L.S.D 5\% & & & 1.49 & 1.72 & 1.37 & 0.30 \\
\hline \multirow{3}{*}{ K-Levels } & Zero K & & 31.83 & 34.66 & 10.80 & 11.75 \\
\hline & $50 \mathrm{~K}_{2} \mathrm{O}$ & & 39.58 & 42.91 & 13.35 & 14.60 \\
\hline & $100 \mathrm{~K}_{2} \mathrm{O}$ & & 49.75 & 57.08 & 16.45 & 19.40 \\
\hline L.S.D $5 \%$ & & & 1.64 & 1.56 & 1.17 & 0.52 \\
\hline
\end{tabular}


Table 8. The effect of animals manure and potassium fertilizers on anthocyanine, starch and total soluble solids of Anna apple fruits

\begin{tabular}{|c|c|c|c|c|c|c|c|c|}
\hline \multicolumn{3}{|c|}{ Treatments } & \multicolumn{2}{|c|}{$\begin{array}{l}\text { Anthocyanine } \\
\text { (mg/100gm) }\end{array}$} & \multicolumn{2}{|c|}{$\begin{array}{c}\text { Starch } \\
(\%)\end{array}$} & \multicolumn{2}{|c|}{$\begin{array}{c}\text { Total soluble solids } \\
(\%)\end{array}$} \\
\hline & & & $2008 / 2009$ & $2009 / 2010$ & $2008 / 2009$ & $2009 / 2010$ & $2008 / 2009$ & $2009 / 2010$ \\
\hline \multirow{6}{*}{$\begin{array}{l}\text { Cattle } \\
\text { manure }\end{array}$} & $\mathrm{K}_{2} \mathrm{SO}_{4}$ & 0 & 16.1 & 15.7 & 3.1 & 3.2 & 9.33 & 9.67 \\
\hline & & 50 & 16.8 & 16.3 & 3.3 & 3.5 & 9.67 & 10.00 \\
\hline & & 100 & 17.6 & 17.2 & 3.5 & 3.7 & 10.00 & 11.33 \\
\hline & $\mathrm{KCl}$ & 0 & 16.2 & 15.8 & 3.0 & 3.3 & 9.43 & 9.85 \\
\hline & & 50 & 17.3 & 17.3 & 3.5 & 3.8 & 11.00 & 11.59 \\
\hline & & 100 & 18.0 & 17.8 & 3.6 & 4.1 & 11.67 & 12.57 \\
\hline \multirow{6}{*}{$\begin{array}{l}\text { Horse } \\
\text { manure }\end{array}$} & $\mathrm{K}_{2} \mathrm{SO}_{4}$ & 0 & 16.4 & 15.9 & 3.1 & 3.4 & 9.67 & 9.33 \\
\hline & & 50 & 17.2 & 17.2 & 3.4 & 3.7 & 10.67 & 11.00 \\
\hline & & 100 & 17.8 & 17.7 & 3.6 & 4.1 & 11.68 & 11.33 \\
\hline & $\mathrm{KCl}$ & 0 & 16.5 & 16.0 & 3.1 & 3.3 & 9.72 & 9.42 \\
\hline & & 50 & 17.5 & 17.7 & 3.4 & 4.0 & 11.00 & 11.34 \\
\hline & & 100 & 18.3 & 18.5 & 3.7 & 4.3 & 12.00 & 13.00 \\
\hline L.S.D. 0.05 & & & 0.343 & 0.31 & 0.19 & 0.22 & 1.219 & 1.41 \\
\hline \multirow{2}{*}{ Manures } & Cattle & & 16.97 & 16.68 & 3.36 & 3.59 & 10.333 & 11.11 \\
\hline & Horse & & 17.26 & 17.05 & 3.38 & 3.80 & 10.972 & 10.83 \\
\hline L.S.D 5\% & & & 0.33 & 0.38 & 0.19 & 0.19 & 0.119 & 0.238 \\
\hline \multirow{2}{*}{ K-Type } & $\mathrm{K}_{2} \mathrm{SO}_{4}$ & & 16.97 & 16.62 & 3.33 & 3.61 & 10.333 & 11.82 \\
\hline & $\mathrm{KCl}$ & & 17.26 & 17.11 & 3.41 & 3.79 & 10.972 & 11.28 \\
\hline L.S.D 5\% & & & 0.11 & 0.26 & 0.11 & 0.10 & 0.385 & 0.427 \\
\hline \multirow{3}{*}{ K-Levels } & Zero K & & 16.26 & 15.83 & 3.10 & 3.28 & 9.75 & 9.51 \\
\hline & $50 \mathrm{~K}_{2} \mathrm{O}$ & & 17.18 & 17.04 & 3.41 & 3.75 & 10.75 & 11.01 \\
\hline & $100 \mathrm{~K}_{2} \mathrm{O}$ & & 17.90 & 17.72 & 3.61 & 4.06 & 11.458 & 12.05 \\
\hline L.S.D 5\% & & & 0.17 & 0.15 & 0.09 & 0.11 & 0.609 & 0.42 \\
\hline
\end{tabular}

apple fruits quality (anthocyanine, starch and TSS) during the two growing seasons.

\subsection{Main effect}

The obtained values in Table (8) were (17.26 and 16.97) for anthocyanine $\mathrm{mg} / 100 \mathrm{gr}$ fresh weight for horse and cattle manure, (3.38 and 3.36) for starch percent and (10.97 and 10.33) for total soluble solids in first investigation season and likewise the same trend in the second season. These results are in accordance with that obtained by Abd El-Naby (2000), Gobara et al. (2001), Abd El-Aal et al. (2001) and Eman et al. (2008).

\subsection{Interaction effect}

Combined effect of organic amendment type, type of potassium and three potassium levels presented in Table (8) indicated that anthocyanine, starch and TSS significantly increased by adding horse manure and increasing the rates of potassium fertilizer (in form of $\mathrm{KCl})$ in both seasons. Attaela (1997) and El-Morshedy (1997) they reported that potassium fertilization on apple trees caused increased in fruit weight, fruit TSS and total sugars. These results are in harmony with that obtained by Gilberto Nava et al. (2008) they indicated that potassium fertilization positively affected fruit color and TSS on Fuji apple cv. Generally, $20 \mathrm{~m}^{3}$ horse manure/ fed/ year $+100 \mathrm{Kg} \mathrm{K} \mathrm{K}_{2} \mathrm{O}(\mathrm{KCl}) /$ fed/ year gave the best results.

\section{6- Fruit quality 2}

Data accessible in Table (9) highlight main and interaction effects of the three tested factors in trial on Anna apple fruit quality. The obtained results showedthat their was significant property due to the treatments on the apple fruit quality fruit firmness, total sugars and titratable acidity during the two growing seasons.

\subsection{Main effect}

Table (9) cleared value were $(0.82$ and 8.81$)$ for fruit firmness $\left(\mathrm{lb} / \mathrm{inch}^{2}\right),(7.65$ and 7.16$)$ for total sugars percent and (0.76 and 0.82) for titratable acidity for horse and cattle manure during the first season and likewise the obtained data gave the same trend in the second season. The results indicated that horse manure more pronounced than cattle manure in enhancing fruit firmness, total sugars and decreasing acidity with non significant differences during two growing seasons.

\subsection{Interaction effect}

Interaction effects of organic amendment type, potassium type and potassium rate fertilizer to Anna apple trees on the fruit quality were presented in Table 
(9). It is comprehensible that all most interactions were statistically significant. This was clear with all considered quality parameters. Nearly all prominent increases in fruit firmness and total sugars but acidity was decreased. The obtained results were in agreement with these reported by El-Kouny et al. (2004), Neilsen et al. (2004), Awad and El-Shenawi (2005) and Moulton et al. (2007).

\section{7- Leaves mineral content}

Data presented in Table (10) show that main and interaction effects of the three tested factors including organic amendment type, type of potassium and rate of potassium. The results indicated that there were significant effects due to the treatments on the Anna apple leaves macronutrients including $\mathrm{N}, \mathrm{P}$ and $\mathrm{K} \%$ during the two growing seasons.

\subsection{Main effect}

Significant differences between N, P and K \% due to the organic amendment type were presented. The results indicated that horse manure more effective than cattle manure in supplying $\mathrm{N}, \mathrm{P}$ and $\mathrm{K}$ during the two growing seasons. The highest results recorded in Table (10) were (1.99 and 1.71) for leaf $\mathrm{N}$ percent, (0.22 and 0.19) for leaf $\mathrm{P}$ content percent and (1.368 and 1.305) for leaf
$\mathrm{K}$ percent for horse and cattle manures, respectively, in first season and the same trend was obtained in the second season. Gething (1986) found K supply to the plant affects nitrogen efficiency. But there is evidence of a more direct connection between the two elements, that $\mathrm{K}$ ion acts as a carrier for nitrate from the root to the leaf, where proteins are synthesized. Also $\mathrm{K}$ ion, being very mobile, promotes the uptake of the nitrate by the root. These results were similar to those of Agnello et al. (1999) and Magda (2002).

\subsection{Interaction effect}

Combined effects of organic amendment type, type of potassium and three of potassium levels on the $\mathrm{N}, \mathrm{P}$ and $\mathrm{K}$ content were presented in Table (10). Most possible interactions for $\mathrm{N}, \mathrm{P}$ and $\mathrm{K}$ were statistically significant, which indicate a high degree of interdependence between the studied factors. The most pronounced increases in $\mathrm{N}, \mathrm{P}$ and $\mathrm{K}$ were obtained for the combination of horse or cattle manure with high rate of $\mathrm{KCl}$ in both growing seasons. Generally, results in Table (10) revealed that increasing the rates of potassium sulfate or chloride and adding organic manure associated with a gradual and significant increase in percentage of NPK in leaves of Anna apple trees in both

Table 9. The effect of animals manure and potassium fertilizers on fruit firmness total sugars and titratable acidity of Anna apple trees

\begin{tabular}{|c|c|c|c|c|c|c|c|c|}
\hline \multicolumn{3}{|c|}{ Treatments } & \multicolumn{2}{|c|}{$\begin{array}{l}\text { Fruit firmness } \\
\left(\mathbf{l b} / \text { inch }^{2}\right)\end{array}$} & \multicolumn{2}{|c|}{$\begin{array}{c}\text { Total sugars } \\
(\%)\end{array}$} & \multicolumn{2}{|c|}{$\begin{array}{c}\text { Titratable acidity } \\
(\%)\end{array}$} \\
\hline & & & $2008 / 2009$ & $2009 / 2010$ & $2008 / 2009$ & $2009 / 2010$ & $2008 / 2009$ & $2009 / 2010$ \\
\hline \multirow{6}{*}{ Cattle manure } & $\mathrm{K}_{2} \mathrm{SO}_{4}$ & 0 & 8.30 & 8.60 & 7.00 & 7.20 & 0.92 & 0.84 \\
\hline & & 50 & 8.50 & 8.90 & 7.30 & 7.60 & 0.81 & 0.73 \\
\hline & & 100 & 8.90 & 10.20 & 7.60 & 7.80 & 0.72 & 0.72 \\
\hline & $\mathrm{KCl}$ & 0 & 8.50 & 8.80 & 7.10 & 7.10 & 0.93 & 0.85 \\
\hline & & 50 & 9.10 & 10.60 & 7.40 & 7.70 & 0.85 & 0.72 \\
\hline & & 100 & 9.70 & 11.10 & 7.70 & 8.30 & 0.73 & 0.67 \\
\hline \multirow{6}{*}{ Horse manure } & $\mathrm{K}_{2} \mathrm{SO}_{4}$ & 0 & 8.80 & 8.90 & 7.20 & 7.40 & 0.87 & 0.78 \\
\hline & & 50 & 9.20 & 9.70 & 7.60 & 7.80 & 0.78 & 0.67 \\
\hline & & 100 & 9.50 & 10.80 & 7.90 & 8.60 & 0.70 & 0.64 \\
\hline & $\mathrm{KCl}$ & 0 & 8.70 & 8.80 & 7.20 & 7.30 & 0.88 & 0.76 \\
\hline & & 50 & 11.40 & 11.50 & 7.60 & 8.40 & 0.68 & 0.66 \\
\hline & & 100 & 11.50 & 12.50 & 8.30 & 8.80 & 0.64 & 0.61 \\
\hline L.S.D. 0.05 & & & 0.75 & 0.81 & 0.09 & 0.05 & 0.08 & 0.08 \\
\hline \multirow{2}{*}{ Manures } & Cattle & & 8.81 & 9.507 & 7.16 & 7.66 & 0.82 & 0.752 \\
\hline & Horse & & 9.82 & 10.215 & 7.65 & 7.95 & 0.76 & 0.692 \\
\hline L.S.D $5 \%$ & & & 1.41 & 0.85 & 0.67 & 0.19 & 0.09 & 0.06 \\
\hline \multirow{2}{*}{ K-Type } & $\mathrm{K}_{2} \mathrm{SO}_{4}$ & & 8.83 & 9.66 & 7.27 & 7.65 & 0.80 & 0.73 \\
\hline & $\mathrm{KCl}$ & & 9.80 & 10.22 & 7.54 & 7.95 & 0.78 & 0.71 \\
\hline L.S.D 5\% & & & 0.40 & 0.39 & 0.46 & 0.87 & 0.02 & $\mathbf{0 . 0 3}$ \\
\hline \multirow{3}{*}{ K-Levels } & Zero K & & 8.53 & 8.716 & 6.83 & 7.30 & 0.89 & 0.81 \\
\hline & $50 \mathrm{~K}_{2} \mathrm{O}$ & & 9.52 & 10.166 & 7.50 & 7.91 & 0.78 & 0.70 \\
\hline & $100 \mathrm{~K}_{2} \mathrm{O}$ & & 9.93 & 10.524 & 7.90 & 8.20 & 0.70 & 0.66 \\
\hline L.S.D 5\% & & & 0.38 & 0.385 & 0.51 & 0.15 & 0.04 & 0.03 \\
\hline
\end{tabular}


Table 10. The effect of animals manure and potassium fertilizers on leaf $N, P$ and $K$ content of Anna apple trees

\begin{tabular}{|c|c|c|c|c|c|c|c|c|}
\hline \multirow{2}{*}{\multicolumn{3}{|c|}{ Treatments }} & \multicolumn{2}{|c|}{$\mathbf{N}(\%)$} & \multicolumn{2}{|c|}{ P (\%) } & \multicolumn{2}{|c|}{ K (\%) } \\
\hline & & & $2008 / 2009$ & $2009 / 2010$ & $2008 / 2009$ & $2009 / 2010$ & $2008 / 2009$ & $2009 / 2010$ \\
\hline \multirow{6}{*}{$\begin{array}{l}\text { Cattle } \\
\text { manure }\end{array}$} & $\mathrm{K}_{2} \mathrm{SO}_{4}$ & 0 & 1.70 & 1.73 & 0.19 & 0.18 & 1.22 & 1.02 \\
\hline & & 50 & 1.72 & 1.77 & 0.18 & 0.18 & 1.27 & 1.41 \\
\hline & & 100 & 1.73 & 1.75 & 0.19 & 0.19 & 1.37 & 1.67 \\
\hline & $\mathrm{KCl}$ & 0 & 1.70 & 1.72 & 0.19 & 0.19 & 1.24 & 1.10 \\
\hline & & 50 & 1.72 & 1.76 & 0.19 & 0.18 & 1.35 & 1.60 \\
\hline & & 100 & 1.73 & 1.77 & 0.18 & 0.19 & 1.40 & 1.64 \\
\hline \multirow{6}{*}{$\begin{array}{l}\text { Horse } \\
\text { manure }\end{array}$} & $\mathrm{K}_{2} \mathrm{SO}_{4}$ & 0 & 1.87 & 1.87 & 0.21 & 0.24 & 1.30 & 1.21 \\
\hline & & 50 & 1.95 & 2.02 & 0.21 & 0.24 & 1.39 & 1.44 \\
\hline & & 100 & 2.09 & 2.09 & 0.21 & 0.23 & 1.43 & 1.65 \\
\hline & $\mathrm{KCl}$ & 0 & 1.88 & 1.89 & 0.21 & 0.23 & 1.32 & 1.23 \\
\hline & & 50 & 2.03 & 2.11 & 0.22 & 0.23 & 1.37 & 1.61 \\
\hline & & 100 & 2.09 & 2.05 & 0.22 & 0.23 & 1.42 & 1.71 \\
\hline L.S.D. 0.05 & & & 0.03 & 0.02 & 0.02 & 0.02 & 0.02 & 0.02 \\
\hline \multirow{2}{*}{ Manures } & Cattle & & 1.71 & 1.71 & 0.19 & 0.19 & 1.31 & 1.39 \\
\hline & Horse & & 1.99 & 2.01 & 0.22 & 0.23 & 1.37 & 1.47 \\
\hline L.S.D $5 \%$ & & & 0.14 & 0.22 & 0.02 & 0.04 & 0.07 & 0.20 \\
\hline \multirow{2}{*}{ K-Туре } & $\mathrm{K}_{2} \mathrm{SO}_{4}$ & & 1.84 & 1.84 & 0.20 & 0.21 & 1.33 & 1.40 \\
\hline & $\mathrm{KCl}$ & & 1.86 & 1.87 & 0.20 & 0.21 & 1.34 & 1.47 \\
\hline L.S.D $5 \%$ & & & 0.05 & 0.07 & 1.80 & 0.01 & 0.01 & 0.03 \\
\hline \multirow{3}{*}{ K-Levels } & Zero K & & 1.79 & 1.80 & 0.20 & 0.21 & 1.26 & 1.11 \\
\hline & $50 \mathrm{~K}_{2} \mathrm{O}$ & & 1.85 & 1.86 & 0.20 & 0.21 & 1.35 & $1 . .51$ \\
\hline & $100 \mathrm{~K}_{2} \mathrm{O}$ & & 1.91 & 1.92 & 0.20 & 0.21 & 1.40 & 1.67 \\
\hline L.S.D 5\% & & & 0.08 & 0.09 & 0.01 & 0.01 & 0.02 & 0.08 \\
\hline
\end{tabular}

seasons. These results were similar to those of Andrzinj Komosa and Adam Szewezuk (2003); Neilsen et al. (2004); Awad and El-Shenawi (2005); Fayed (2005) and Neilsen and Neilsen (2007).

In all Tables, horse manure and potassium chloride increased number of leaves/ shoot, leaf area, number of flowers/ cluster, fruit set $\%$, fruit weight (gm), length $(\mathrm{cm})$ and diameter $(\mathrm{cm})$, yield $(\mathrm{kg} / \mathrm{tree}$ and ton/ fed), anthocyanine $(\mathrm{mg} / 100 \mathrm{gm})$, starch $\%$, total soluble solids $\%$, fruit firmness $\left(\mathrm{lb} / \mathrm{inch}^{2}\right)$, total sugars $\%$ and leaf ( $\mathrm{N}$ content $\%, \mathrm{P}$ content $\%$ and $\mathrm{K}$ content $\%$ ) in two seasons. On the other hand, titratable acidity was decreased. Finding of many investigated gave a real support to our results, Awad and El-Shenawi (2005); Eman et al. (2008) and Eman et al. (2010).

\section{CONCLUSION}

From the results of this investigation, it could be concluded that fertilization of Anna apple trees with organic manure (horse or cattle) $20 \mathrm{~m}^{3} /$ feddan /year plus $100 \mathrm{~kg} \mathrm{k2O} /$ feddan / year seems to be the promising treatment to produce the highest vegetative growth ,yield characters, fruit quality and mineral composition. This treatment is considered to be recommended for fertilizing Anna apple trees under the prevailing conditions of this study. It will keep out environment clean, decrease the environment pollution and fertilizers loss resulted from applying high rates.

\section{REFERENCES}

Abd El-Aal A.H.and F.F. Ahmed. 2001. The necessary potassium for Flame seedless grapevines irrigated with saline water. The Fifth Arabian Horticulture Conference, Ismailia, Egypt, March 24-28 p.75-82.

Abd El-Hadi, A.H. 1989.Potassium and its effect on the productivity of crops in the Egyptian soils. (Arabic), Puplished by soils \& water Res. Institute, Agric. Res. Center.

Abd El-Hadi, A.H., M.S. Khadr and M.A. Hassan. 1990. Effect of fertilization on the productivity of major field crops under intensive cropping system in Egypt. $3^{\text {rd }}$ International Congress Programe of Soil Sci.of Pakistan,March 20-22.

Abd El-Naby, S.K. M. 2000. Effect of banana compost as organic manure on growth, nutrients status, yield and fruit quality of Maghrabi banana. Assuit Jour. Of Agric. Sci., (3): 101-114.

Abou El-Khashab, A.M.; Safia, A. Taleb and Wafaa, T. Saeed. 2005. Aggezi and Koroneiki olive trees as affected by organic and bio-fertilizer, calcium citrate and potassium. Arab Univ., J. Agric. Sci. Ain Shams Univ., Cairo, 13 (2), 419-440. 
Agnello, A.M., W.F.Wilcox, W.C.Stiles,J.Kovach, and P.D.Curtis. 1999. Pest management recommendations for commercial tree - fruit production. Cornell Univ. SAES Geneva.

Andrzej Komosa and Adam Szewczuk, 2003. Effect of soil potassium level and different potassium fertilizer forms on nutritional status, growth and yield of apple trees in the first three years after planting. Pesq. Agropec. Bras.V ol. 38 No.4 Brasilia Apr.2003.

A.O.A.C. 2000.Association of Official Agriculture Chemists. Official and Tentative Methods of Analysis, $9^{\text {th }}$ Ed.Washington, DC.,USA.

Attala, E.S.1997.Effect of potassium fertilization on Anna apple trees grown in sandy soils of Egypt.Egypt J.Agric.Res.,75(4):1069-1080.

Awad A.M. and M.R. El-Shenawi. 2005. Integrated production tchnique for banana "Williams" using organic and mineral $\mathrm{NK}$ fertilization in calcareous soils. Assiut Journal of Agricultural Scince, Vol.36, No4, 2005.

Badran, N.M.,M.E.A.Khalil and M.A.A.El-Eman. 2000.Availability of N,P,and K in sandy and clayey soils as affected by the addition of organic materials. Egypt.J.Soil. Sci. 40, No.1-2, pp. 265-283.

Cassman, K.G., Steiner, R. and Johnson, A.E. 1995. Long Term Experiments and Productivity Indexes to Evaluate the Sustainability of Croping Systems. Chap. II in Agriculture sustainability. Economic, Environmental and Statistical Considerations. Edited by Barnett, V.R. Payne and R. Steiner UK: John Wiley \& Son.

CoHort Software. 1986. Costat Statistical package (version 3.03), P.O.Box 1149, Berkeley, CA, 94701, USA.

El-Kouny, H.M., El-Assar,A.M. and Mohamed,S.G. 2004. Effectiveness of natural organic amendments, biologically affected compost, and mineral fertilization sources of potassium in improving soil properties and productivity of "Zaghloul cv." Date palm in calcareous soils. Assiut Journal of agricultural Scince, Vol. 35, No. 2, 2004.

El-Morshedy, F.A. 1997. Fertigation studies on Anna apple trees. Alex. J.Agric.Res., 42(2) : 101-111.

El-Shenawi,M.R. 2000. Effect of $\mathrm{N}$ and $\mathrm{K}$ fertilization on growth, yield, fruit quality and leaf mineral content of Williams banana grown in calcareous soils. Ph.D. Thesis. In Pomology, Fac. Agric. Alex. Univ., Alex. Egypt.

El-Shenawi, M.R. and S.A.M. El-Sayed. 2005. Effect of bio and organic fertilization on growth, productivity, fruit quality and leaf mineral content of GrandNain banana. J. Agric. Res. (Fac. Agric. Saba Basha) vol.10 (3), 2005.

Eman, A.A. Abd El-Monem, M.M.S. Saleh and E.A.M. Mostafa. 2008. Minimizing the quantity of mineral nitrogen fertilizers on grapevine by using humic acid, organic and biofertilizers. Res. J. of Agric. And Biological Sci. 4 (1): 46-50.

Eman, E.K. Abd-Ella, S.S. Mervate and A.Z. Waffaa. 2010. Effect of some organic and mineral fertilizer applications on growth and productivity of pomegranate trees. Alex. Sci. Exchange J. Vol. 31, P. 296-304.

FAO. 1980. Soil and plant analysis as basis of fertilizer recommendations. Cottonie A. (Ed.); Soils bulletin N. 38 (2). Rome.
Fayed, TA. 2005. Effect of some organic manures and Biofertilizers onAnna apple trees 1-Vegetative growth and leaf chemical conistitutes.Egypt.J.Appl.Sci; 20(1): 159175. 2005.

Gething, P.A. 1986. Improving returns from nitrogen fertilizer "The potassium nitrogen partnership" IPI research topic No., 13. International Potash Institute, Bern/ Switzerland.

Gilberto Nava; Antonio Roquo Dechen; Gilmar Ribeito Nachtigall. 2008. Nitrogen and potassium fertilization affect apple fruit quality in southern Brazil. Communication in Soil Science and Plant Analysis Vol. 39, Issue $1 \& 2$ January 2008 pp. 96-107.

Gobara, A.A., F.F. Ahmed and M.S. El-Shama. 2001. Effect of varying $\mathrm{N}, \mathrm{K}$ and $\mathrm{Mg}$ ratios on growth, leaf chemical composition and productivity of Banaty grapevines. The Fifth Arabian Horticulture Conference, Ismailia, Egypt, March 24-28 (83-88).

Hanson, Fric. 1996. Mineral Nutrition of Plants. $2^{\text {nd }}$ Ed. Academic Press, London.

Magda, H.M. 2002. Studies on fertilization of Washington Navel orange Trees. Ph.D. Thesis. Fac. of Agric., Moshtohor, Zagazig University.

Mahmoud, M.M.M. 1994. Microbiogical studies on the management of urban wastes. Ph.D. Thesis, Fac. of Agric., Moshtohor, Zagazig Univ. Egypt.

Marschner, H. 1995. Mineral nutrition of higher plants. $2^{\text {nd }} \mathrm{ed.}$ Academic Press, London.

Mengel, K. 1997. Impact of potassium on crop yield and quality with regard to economical and ecological aspects. In food security in the WANA region, the essential need for balanced fertilization (A.E. Johanston,ed.) PP. 157174. International Potash Institute, Basel, Switzer land.

Montasser, S.Y.B. 1987. Organic manuring and behavior of certain elements in Egyptian soils with special reference to response of grown plants. Ph. D. Thesis. Fac. of Agric. Ain.Shams Univ., Egypt.

Moulton, G.A., J. King, J. Price and R.S. Darland. 2007. Completion report: the effect of potassium and magnesium applied fertility on Jonagold apple quality. WSUNorthwest Washington Research and Extension Center 16650 State Route 536, Mount Vernon, WA 98273.

Naik, M.H. and R. SriHari Babu. 2007. Feassibility of organic farming in guava (Pisidium guajava, L.) Acta Horticulturae. No. 735.

Neilsen, G.H. and D. Neilsen. 2007. The effect of k fertilization on apple fruit $\mathrm{Ca}$ concentration and quality. ISHS Acta Horticulture 721: V International Symposium Mineral Nutrition of Fruit Plants.

Neilsen, G.H. and D.Neilsen,L.C.Herbert and E.J.Hogue. 2004. Response of apple to fertilization of $\mathrm{N}$ and $\mathrm{K}$ under conditions susceptible to the development of K deficiency. J.Amer. Soc.Hort.Sci. 129(1): 26-31.2004.

Page,A.L.(ed).1982. Methods of soil analysis, part2. Book series No.9. Am.Soc.of Agron. and Soil Sci.Soc.Am., Madison, Wisconsin, USA.

Rabino ,L.;LAlberto and M.K.Monrad. 1977. Photocontrol of anthocyanin synthesis. J. Plant physiol., 59: 569-573. 
Saleh, M.M.S., S. El-ashry and A.M. Gomaa. 2006. Performance of Thompson seedless grapevine as influenced by organic fertilizer, humic acied and biofertilizers under sandy soil conditions. Res. J. of Agric. And Biological Sci., 2 (6): 467-471.

Snedecor, G.W. and W.G. Cochran. 1990. Statistical methods $7^{\text {th }}$ ed. Lowa. State Univ. Press. Ames. Lowa.

Soliman, S.S., M.R. El-Sonbaty and M.A. Ahmed. 2006. Effect of organic manures on growth, yield, fruit quality and some mineral content of Maghrabi banana. Minufiya. J. Agric. Res. Vol. 31, No. (5): 1179-1197.

Steel, R.G. and J.H. Torrie. 1980. Principles and procedures of statistics $2^{\text {nd }}$ ed., McGraw-Hill Book Comp. New York, U.S.A., pp.328.

Stiles, C.P. and W.S. Reid. 1991. Orchard nutrition management. Cornell Univ.Coop Ext. Info. Bul.219.

Westerman, R.L. (ed). 1990. Soil testing and plant analysis. Third edition, Soil Sci. Soc. Am., Madison Wisconsin U.S.A. 


\section{الملخص العربي}

\section{أنَا العضوى والبوتاسى على نمو ومصول وجودة ثمار التفاح صنف تأثيرالتسميد}

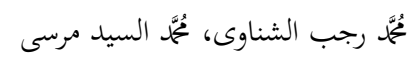

لكل من الأنثوسيانين والنشا والمواد الصلبة الذائبة الكلية ومتوسط

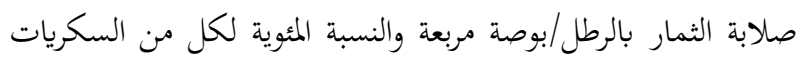
الكلية والحموضة ومحتوى النيتروجين والفوسفور والبوتاسيوم في الأوراق)، كما أوضحت النتائج أن زيادة معدل تركيز البوتاسيوم

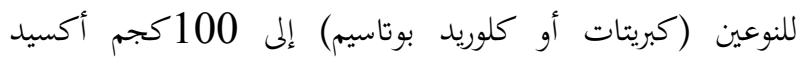
بوتاسيوم لكل فدان أدى إلى زيادة معنويه لكل الخصائص المختبره

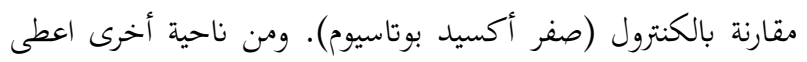

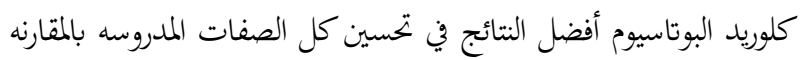
بكبريتات البوتاسيوم. كذلك اوضحت النتائج ان أفضل معامله كانت عند استخدام 20م3 سماد عضوى (خيل او ماشية)/ فدان/عام مع 100

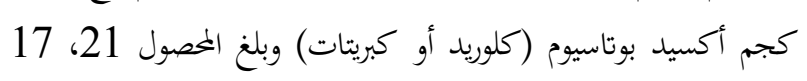

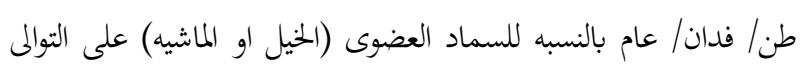

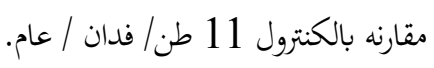

اجريت هذه الدراسه في مزرعة خاصه بمنطقة العكريشة-كفر

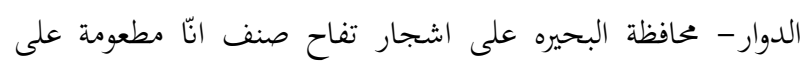
اصل بلدى عمرها 8سنوات تحت نظام الرى السطحى خلال موسمى النمو 2008/ 2009 و2010/2009 والهدف من البحث هو تقدير استجابة اشجار التفاح الانا لنوع السماد العضوى (ماشيه او خيل) بمعدل 25 كيلو جرام/ شجرة/ عام (20 م3/ف) مع نوعين مختلفين من التسميد البوتاسى (كبريتات وكلوريد بوتاسيوم ) مع ثلآث مستويات من كل نوع هى صفر ،50 ، 100 كجم اكسيد

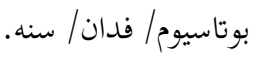
أوضحت نتائج الدراسه ان السماد العضوى للخيل كان اكثر تأثيرا من سماد الماشيه على تحسين الصفات المدروسة (عدد الأوراق لكل فيع ومساحة الورقة وعدد الأزهار لكل دابرة ونسبة الثمار العاقدة ووزن وطول الثمرة وقطرها والمصصول والنسبة المئوية 